\title{
Prakāśa. A few reflections on the Advaitic understanding of consciousness as presence and its relevance for philosophy of mind
}

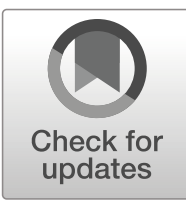

\section{Wolfgang Fasching ${ }^{1}$}

Published online: 14 August 2020

(C) The Author(s) 2020

\begin{abstract}
For Advaita Vedānta, consciousness is to be distinguished from all contents of consciousness that might be introspectively detectable: It is precisely consciousness of whatever contents it is conscious of and not itself one of these contents. Its only nature is, Advaita holds, prakāśa (manifestation); in itself it is devoid of any content or structure and can never become an object. This paper elaborates on this kind of understanding of consciousness in order to next explain why it might be fruitful for developing a clear understanding of the nature of the so-called problem of consciousness. Today's philosophy of mind tends to conceive of consciousness in terms of qualia, thereby taking it as a special kind of (introspectively accessible) object. This renders the antimaterialist claim of the distinctness of consciousness from all physical (publicly accessible) features vulnerable to the materialist reply that the difference in question might be a merely epistemological matter, i.e., a matter of different modes of givenness without difference in what is thus given. This move, however - this paper argues -, is impossible without resulting in circularity or infinite regress with regard to consciousness in the sense of givenness (manifestation) itself.
\end{abstract}

KEY WORDS Advaita Vedānta $\cdot$ Consciousness · Materialism · Transparency

\section{Introduction}

In this paper, I wish to discuss, from a modern Western perspective, the understanding of consciousness we find in the classical Indian school of Advaita Vedānta (as I understand it, not being a scholar of Indian thought) and to explain why I think that it harbours valuable insights into the nature of consciousness that might prove useful

Wolfgang Fasching

w.fasching@univie.ac.at

1 Department of Philosophy, University of Vienna, Universitätsstraße 7, 1010 Vienna, Austria 
for present discussions in philosophy of mind (in particular with regard to the "hard problem of consciousness"). My topic here is not the monistic metaphysic of Advaita (the identity of consciousness with brahman, the absolute), but exclusively its phenomenological analysis of the conscious mind as it is immediately given in our everyday life.

The nature of consciousness (cit) is the central topic of Advaita Vedānta. For the Advaitins, consciousness is the very being of the subject (the "self", attman) in contrast to our usual identification of certain configurations of objective contents we are conscious of (the empirical person, jīva) as our self, and the soteriological goal is accordingly seen in the deconstruction of such selfobjectifications that conceal our true essence (cf. e.g. Ram-Prasad 2011, 221, 226, 230). So what it is that Advaita invites us to is a radical turn away from any objects of consciousness towards consciousness itself. What does that mean? One might first be tempted to understand it as requiring attending, instead of the objects of the external world, to the inner goings-on of one's conscious mind, to the succession of the mental pictures, sensations, thoughts, impulses, etc. that may be possible to find in meticulous introspection. Yet actually this is not at all what Advaita means: In the Advaitic view, all mental goings-on are objects of consciousness too, and not consciousness itself. The identification of the self with consciousness does not mean that we consist of the mass of contents of consciousness we may introspectively find, but precisely that we exist as consciousness (which in Advaita, as in many Indian schools, is strictly distinguished from the mind (e.g. antahkarana) and its modifications (vrttis)).

For Advaita, "the description of consciousness rests upon one predication, that is, manifestation or prakāśa. It is often described in the Advaita literature as prakāśa eka rasa, meaning that which has only one rasa or essence, that is, manifestation" (Gupta 2003, 103). ${ }^{1}$ In itself, it is without any form or content (nirākāra) and non-objective (avișaya) (Mohanty 1993). Yet although it can never be given as an object, it is in no way concealed, rather it is essentially self-disclosing (svaprakāśa), i.e. its very being is its own revealedness without any subject-object difference.

In the following I will first discuss this kind of view from a phenomenological perspective in order to get a clear grasp of how it is to be understood that consciousness qua mere happening of manifestation is to be distinguished from the conscious mind in the sense of the introspectively accessible contents of consciousness. In the second part I will say a few words on why I think that this distinction is fruitful for developing a clear understanding of the essence of consciousness and therefore of the so-called problem of consciousness which, in my view, tends to be obscured in philosophy of mind by the latter's focusing on the qualia (only subjectively accessible qualities) instead of on consciousness as such. In particular I will focus on what Chalmers calls the type-B materialist strategy which might make sense with regard to qualia, but not - or so I will argue - to consciousness in the proposed sense.

\footnotetext{
${ }^{1}$ Prakäśa literally means "light" or "illumination". In Indian philosophy the term is used for "the capacity to disclose, present, or make manifest" (MacKenzie 2017, 335; cf. also Ram-Prasad 2007, 53).
} 


\section{On the understanding of consciousness as prakāśa}

\subsection{Consciousness as presence}

According to Advaita Vedānta, the absolute is pure, qualityless and unchanging consciousness. Our consciousness (the consciousness of individual conscious entities) is not distinct from it, but is nothing other than this absolute itself, (seemingly) modified by the mental states of respective individual minds so that it is one and the same absolute that, as it were, looks at the world from the perspectives of all the innumerable experiencing creatures of the universe (cf. e.g. Ram-Prasad 2001, 177-180).

This metaphysical claim is of no concern to us here - yet with this (Upaniśadic) background, the Advaitins developed a keen sense of the element of consciousness as such in our mental lives as something that, in their view, is devoid of all qualities of its own and utterly unobjectifiable and which remains unaffected by the permanent change of mental contents. Consciousness functions within ourselves as sākșin, "witness", in the sense of a passive, uninvolved observer of our mental states (vrttis) and thereby simultaneously of their objects - "witness" of course not in the sense of an entity that observes (cf. e.g. Gupta 2003, 103), but as the mere taking-place of witnessing itself. It is passive insofar as all activity lies on the side of the vrttis, whilst the term sākșin refers to the mere happening of their immediate manifestness or presentness, which is not itself an activity and does not add anything to the content of what is being manifested (Gupta 1998, 4 et pass., Gupta 2003, 106, Ram-Prasad 2007, 79, Chatterjee and Dravid 1979, 20). ${ }^{2}$

Hence Advaita strictly distinguishes between mental states (vrttis) and consciousness (cit), the former being objects of consciousness too (even if quite special ones, cf. Chatterjee 1982, 344) and not consciousness itself. Whilst the vrttis are characterized by distinguishable forms or contents ( $\bar{k} k \bar{a} r a)$, consciousness is form- or contentless (nirākāra) (cf. Gupta 2003, 119 f.). Its only essence is prakāśa: It is the principle of manifestation. "The Advaitins argue that without the lustre of pure consciousness, all objects, physical and mental [...], merge in the darkness of nescience. [...] Where there is no consciousness, there is no manifestation of any kind" (Gupta 2003, 106; cf. Chatterjee and Dravid 1979, 75 f.).

Whilst being what makes any objects whatsoever manifest, consciousness can never itself be made an object, for, as Ram-Prasad fittingly states, "[W]hatever is seen, consciousness is not seen, since it is always and only the seeing" (Ram-Prasad 2007, 98; cf. Gupta 1998, 99). Nevertheless, its presence is indubitably and immediately established, since it is the undeniable basis of our knowing anything at all. As the Advaitin Vidyāranya says: "As it is shameful for a man to express doubt if he has a tongue or not, so also it is shameful to say, "I do not know what consciousness is"" (1967, III.20). It is the ever-nonobjective ground of any objects coming to appearance (including ourselves qua empirical persons together with our mental states ${ }^{3}$ ).

Now, is this a plausible view of consciousness? Does it make much sense to distinguish between mental states and consciousness as if these were two different things? Are not our (experiential) mental states precisely states of consciousness - characterized by all kinds of

\footnotetext{
${ }^{2}$ On the concept of sākșin cf. Chatterjee and Dravid 1979, Chatterjee 1982, Gupta 1998.

3 To quote Ram-Prasad: The àtman "is not the self of individuated consciousness", it "is simply the consciousness itself that does the taking [...] of itself as an individual" (2011, 230).
} 
experiential qualities - so that consciousness is by no means elusive, never-to-be-objectified, since attending to one's experiential states just means to attend to one's consciousness? Why posit something completely unobservable in addition to them?

I think there is indeed something to Advaita's rigorous attempt to isolate the element of consciousness as such, and in order to appreciate this, it might be worthwhile to pause for a moment and reflect on what our being conscious actually consists in.

Consciousness is, it seems, the most evident phenomenon of all: Nothing is more certain to me than that I am conscious at the present moment (i.e. that I am neither in a dreamless coma nor an experienceless automaton that only externally simulates the behaviour of a conscious being). Yet what kind of phenomenon is this? I am conscious of many things right now: of the desk in front of me, of the traffic noise in the background, of my body, of the vaguely anticipated train of thought I am trying to develop, etc. Yet what is this consciousness itself? When I try to turn my attention away from the manifold objects I am conscious of to this consciousness of them itself, I have the strange experience that I cannot find it anywhere. If I am invited, for example, to attend instead of the glass I see in front of me to my seeing it (my visual consciousness of it), I am at a loss as to what I am supposed to do, where I should direct my attention, and what I should hope to find there. No "act of seeing" that would be "directed" at the seen object is to be found, still only the latter is there for me (this is what has recently been called the "transparency" of consciousness). I can examine more closely the visual phenomenon, i.e. what I see; yet the seeing itself does not seem to be a phenomenon of its own I could make an object and investigate.

The reason why I cannot find my consciousness as a phenomenon of its own in addition to what I am conscious of is simply that consciousness is just this: consciousness. It does not consist of any contents of consciousness - some inner pictures, feelings or the like - but is precisely consciousness of whatever contents I am conscious of, i.e. it is my being aware of them. And to be conscious of some content means nothing other than that this content is there for me. Consciousness is the presence-for-me of whatever I am conscious of. ${ }^{4}$ If it were

\footnotetext{
${ }^{4}$ For Advaita, the "me" of course is ultimately nothing beyond this very presence itself (cf., e.g., Śankara's commentary on the Bṛhadāranyaka Upanișad, I.4.10: "[T]here is no further conscious seer apart from the seeing" (quoted after Ram-Prasad 2001, 172)).

One could - as did an anonymous reviewer of a previous version of this paper - raise the question of whether it is adequate to speak of "for-me-ness" and "our consciousness" when it comes to the Advaitic understanding of consciousness, since for Advaita, consciousness is ultimately non-individual and its assumed relatedness to an (individual) "I" is considered an illusion (cf. Ram-Prasad 2011). Yet actually, I think (as far as the phenomenal level is concerned) the consciousness Advaita speaks of is precisely the phenomenon of forme-ness; the sākșin is, as MacKenzie (2012) formulates, "the dative, the 'for whom', of any phenomenal manifestation" (2012, 184, fn.), and it is what I really am (and not something outside myself). (Cf. Gupta 2003, 100: "[T] he two, being conscious and myself, are one and the same thing" (my emphasis).) The fact that, for the Advaitin, it is ultimately the same "seer" that lives in every experiencing creature does not change anything about this. My use of the term "for-me-ness" does not imply any commitment to a plurality of subjects; "me" does not necessarily mean "me, not you", but simply: $I$, the subject, the seer which is my true nature.

I do not think that it is true that Advaita outright denies the ätman the status of an "I" in any sense; rather, attman is my (and anyone's) innermost I, the true subject of any givenness. Advaita only rejects our usual understanding of the I as it is expressed in formulations like "I am this" or "I am that" (cf. e.g. the introduction to Śankkara's Brahmasūtrabhāṣya (1920, 3)). As Śankkara says, e.g.: "The learned should abandon the 'this'portion in what is called 'I', understanding that it is not Ätman" (1992, I.6.6) - so that the ätman is precisely the pure I-element after any "this" in one's self-understanding has been dropped. Cf. also Vidyāranyya 1967, VII.88: “(Doubt): If the idea of 'I' is given up, how is the knowledge 'I am Brahman' possible? (Reply): It is the false parts of 'I' which are given up and the true part retained [...]." (Cf. also Fasching 2012, 177-180.)
} 
a further content in addition to the content it is conscious of, it would be precisely just another one of the contents present to me and not the presence of the first content.

The neo-Kantian philosopher Paul Natorp captured, ante litteram, this transparencyobservation concerning consciousness quite clearly when he wrote:

"When I am told to attend to whether I have a particular sound-impression, I will not attend to anything other than to the very sound I am supposed to hear and maybe I will then hear it. Whoever additionally hears or otherwise [...] perceives his hearing, I can perhaps envy his manner of perception, yet I could not follow suit with him. 'The sound sounds to me' and 'I hear the sound' are not two different facts to me - neither two successive ones nor two simultaneously experienced ones [...]. [...] [M]y consciousness (e.g. hearing) is only there or takes place insofar as the content (e.g. sound) is there for me; its thereness for me is my consciousness of it" (Natorp 1888, $17 \mathrm{f}$.).

That is, I think, why Advaita Vedānta can rightly claim that consciousness is nirākāra, formless. It has no distinguishable features of its own, no qualities, structures or modes - all this belongs to what we are conscious of. Just as Natorp writes: "In the basic phenomenon of consciousness there is no manifoldness and specificity whatsoever, it is absolutely simple [...]. Rather, all richness, all manifoldness lies exclusively in the content. The consciousness of a simple sensation does not, qua consciousness, differ at all from the consciousness of a world; the factor of consciousness is just the same in both of them, the difference lying exclusively in the content" (Natorp 1888, 19). Quite comparably, the Advaitin Padmapāda writes: "[T]he particularity (viśeșa) inherent in itself (anubhava [= experience]) is not seen to manifest itself as blueexperience and yellow-experience to the exclusion of any reference to the particularity of the object" $(1948,60)$, which the translator Venkataramiah comments as follows: "In the cognitions - this is blue, this is yellow, the distinctions are due to the distinctness of objects blue and yellow. [...] In jñanna [= cognition] as such there is no internal plurality of distinctions" (ibid.). ${ }^{5}$

Hence, what I wish to suggest is that when the Advaitins characterize the nature of consciousness as prakāśa (manifestation/illumination) or sākṣin (mere witnessing), they mean that it consists in nothing but the taking-place of presence of whatever comes to manifestation in it, without being itself some particular content that presents itself to us. Its "only function, like that of light, is to show the object on which it is focused" (Gupta 2003, 119 f.) - and this pertains to external objects as well as to any mental states such as emotions or thoughts. It is this (notoriously elusive, yet undeniable) taking-place of presence as such that stands at the centre of Advaitic thought (elusive, because it is not any content at which we could direct our gaze, but at the same time undeniable, since it is the very medium of the coming-to-givenness of anything).

\subsection{The multifariousness of experience and the simplicity of consciousness}

Now one could ask whether this is quite right: Is consciousness really just an empty presence without any distinguishable features of its own? It might consist in the givenness of objects to us, but why should there not be various modes of givenness

\footnotetext{
${ }^{5}$ Cf. Sureśvara 1959, II.86: "Each mental cognition of the external world is different according to its object. But the light which illumines these different cognitions is not thus differentiated, since all alike have the common form of consciousness.” Cf. also Vidyāraṇya 1967, I.3.
} 
that can be investigated? Husserl, for example, vehemently objects to Natorp's view. He agrees with him that "its [the content's] thereness for me is my consciousness of it", yet insists "that the 'thereness of a content for me' is a matter that allows for and requires further phenomenological analysis" (Husserl 1984, 394). For example, he points to the fact that one and the same object can be given to me in different ways - e.g. in perception and in imagination - and that there consequently are "different 'modes of consciousness', namely of the intentional relation to objects" (ibid., 400), so that it is not at all correct that "[a]11 richness, all manifoldness of consciousness [...] lies exclusively in the content", as Natorp holds.

So is it true that when I try to attend not to the glass I see in front of me, but to my seeing it, I find nothing but the glass? Well, it is certainly correct that I do not find an act of seeing as an object existing side by side with the object seen. Still only the glass is there for me - but now it is there for me as seen; and there is evidently a difference between the glass as seen and the glass as felt or the glass as imagined or remembered, etc., although it might be given as the very same glass with the same objective properties. So there is a difference between seeing, feeling, imagining, and remembering, and are these not different ways of being conscious of the glass (of its being there for me)? One can concede that consciousness cannot be found independently of the object it is conscious of, since it consists in the givenness-to-me of the object, and still insist that it is not just an empty, featureless presence, but that there are distinguishable modes of givenness and that I can therefore attend, instead of to the given object, to the how of its givenness (cf. Zahavi 2005, 119-123).

This is hard to deny, and for a better understanding of what Advaita Vedānta means when it speaks of the featurelessness and unobjectifiability of consciousness, it might be useful to consider more closely the role of the vrttis with regard to our consciousness of objects. Put in the terminology of Advaita, this objection could be stated in the following way: It is just not true that mental states, vrttis, are simply further objects I am conscious of alongside external objects; rather they are - in the case of cognitive, intentional $v r t t i s^{6}-$ states through which I am conscious of objects, i.e., they are my consciousness of them. And since there are manifold distinguishable forms of objectmanifesting vrttis, there are obviously different forms of being conscious of things (i.e. of things presenting themselves).

The Advaitins do not outright deny this: They concede that it is a respective vrtti in which an object comes to givenness, but they insist that it achieves this by being illuminated by the light of consciousness, which is to be distinguished from it so that knowledge of an object is "neither a vṛtti nor the sākșin, but a blend of both" (Hiriyanna 1956, 344; cf. Ram-Prasad 2007, 80-83).

To get a grip on this view, I would suggest terminologically distinguishing between experiences (in the sense of the experiential or phenomenal contents) and consciousness, the former being that which Advaita calls vrttis qua mental states. There is no question that I am aware of my experiential life or "stream of consciousness" and that it displays a vast manifoldness as well as complex structures I can attend to and investigate. To attend to one's stream of consciousness means to attend to the phenomenal givennesses (givennesses in the sense of what is given) which succeed each

\footnotetext{
${ }^{6}$ The term vrtti encompasses both cognitive and non-cognitive states (Gupta 2003, 113, Sinha 1983a, 37-39), the only difference being that a non-cognitive state "presents no object besides vrtti" (Sinha 1983a, 37).
} 
other in a continuous flux, and this obviously means to attend to the contents that are present in consciousness and that one could call the "experiences" precisely in the sense of what is experientially present (so that it would be more adequate to speak of the stream of experiences instead of the stream of consciousness).

Now it is the case that experiences are often the phenomenal manifestation or appearing of transcendent objects, i.e. objects of consciousness that are given to us as existing independently of their respective givenness: They are given to us as possibly appearing in other experiences (without themselves being different for that reason) and as possibly existing without appearing at all - this belongs to the very sense in which they are given qua transcendent objects. ${ }^{7}$ For that reason it is possible to distinguish between external objects appearing in consciousness and their "subjective" appearances (the respective experiences in which they have their givenness). And while the objects are given as consciousness-transcendent, the appearances have their very being in their being consciously present and are in this sense consciousness-"immanent". Yet this "immanence" does not mean that they are parts of consciousness, i.e. that the latter consists of them - rather, they are immanent in the sense of not existing independently of consciousness (of having their being in being experienced). An experience being experienced differently is ipso facto a different experience, and if it is not experienced, it simply does not take place at all. As Advaita states, whilst "[p]rior to its manifestation [by a respective vrtti], an object, say, a pitcher, is unknown" (Gupta 2003, 111), vrttis have no "unknown existence" (ajñätasattā) (cf. Gupta 1998, 69, Gupta 2003, 111; cf. also Sinha 1983a, 95), but have their very existence in being manifested in consciousness. They are not themselves given in appearances that could be be distinguished from themselves, i.e. through further vrttis (they do not become manifested by virtue of another cognitive act being directed at them). They are, in the terminology of Advaita, manifested exclusively and directly by witness-consciousness (sākṣin) (Gupta 1998, 68 f., Gupta 2003, 109-111), i.e. without the mediation of a further vrtti: "An external object is given through a mental mode. But the mental mode is given directly to the witness-consciousness without needing another mental mode" (Gupta 1998, 70; cf. Chatterjee 1982, 342). ${ }^{8}$ Hence vrttis, in having no being apart from their manifestation in consciousness, are not in the same sense external objects like tables or trees, yet this does not change anything about the fact that they are contents of consciousness - the

\footnotetext{
${ }^{7}$ Advaita Vedānta rejects the Yogācāra Buddhist claim of the identity of cognition and object: "We are obliged to assume objects beyond apperception [cognition], precisely on the ground of apperception itself. For no one apperceives a post or a wall as a mere apperception, but as objects of apperception everyone apperceives the post and the wall" (Śankkara 1920, II.2.28). Śankara also points to the fact "that we distinguish seeing the pot and remembering the pot", the difference lying in the respective cognition, not in the object (ibid.). (On this topic, cf. Ram-Prasad 2002, 25-92.)

${ }^{8}$ Balslev helpfully points out that Advaita distinguishes between three ways in which things are established: External objects are established by pramānas, i.e. the standard empirical "means of knowledge" such as perception or inference (i.e. through cognitive vṛttis) (pramānasiddha); mental states (the vṛttis themselves) are established immediately by witness-consciousness (sākṣisiddha); while consciousness, in turn, is selfestablished (svayam-siddha) (Balslev 2013, 115). This shows that vrttis have in some sense an in-between status: They are neither objects in the usual sense nor are they consciousness itself (cf. Chatterjee and Dravid 1979, 78, Chatterjee 1982, 344).
} 
permanently changing appearances of objects are part of the stream of what is phenomenally present - and not consciousness itself as such.

So the phenomenal manifestation (appearance) of an object brings an object to givenness and is at the same time itself something given. ${ }^{9}$ It is this double character of object-experience which makes it possible to turn one's attention from the appearing object to its appearing itself and to investigate the latter and its distinguishable modes in contrast to the investigation of the objective properties of the object. It is hard to avoid terminological ambiguities in the use of terms like manifestation, givenness, etc., since in some sense it is the appearance in which the manifestation of the object happens ${ }^{10}$ (so that one might be tempted to simply equate the consciousness of an object with the appearances), yet it yields this givenness by virtue of itself being present (cf. Zahavi $2005,121)$, and it is this presence as such that is consciousness in the strict sense. ${ }^{11}$

It must be stressed that there are not $t w o$ presences involved here: The givenness of the appearance of the glass is not a second, higher-order consciousness - a consciousness of the consciousness of the glass. The glass-appearance has its very existence in being-present, and it is present precisely as the appearance of the glass. Therefore, when the glass-appearance is present, ipso facto the glass appears to me. It is one and the same presence, one and the same consciousness, which constitutes the very existence of the glass-appearance and which thereby lets the glass appear (because, again, when the glass-appearance is present, the glass-appearance takes place, i.e.: the glass appears). Precisely in this sense, for Advaita, "the witness consciousness [sākșin] manifests not only the $v r t t i$, but also its object. Hence the expression 'I know the jar' really expresses the fact that pure consciousness as limited by my inner sense [the mind] manifests a vrtti of the same inner sense while this vrtti removes the concealment of its object, the jar" (Gupta 2003, 112; cf. Chatterjee and Dravid 1979, 84). In this way "the Advaitins do accommodate the sākāra theory [saying that consciousness has a form] within their scheme, because on their account, though consciousness has no form, the vrttis do assume the form of the object" (Gupta 2003, 120).

So it is doubtless correct that the givenness of an object is not just a featureless, empty presence that cannot be further analysed. I certainly can attend to the perspectival givenness of an object, and this is something different from attending to the object's objective properties; there are manifold modes of givenness, and each objectgivenness is in itself richly structured, and accordingly complex phenomenological analyses are possible. For instance, we can, to take a standard Husserlian example,

\footnotetext{
${ }^{9}$ Cf. Sureśvara 1959, II.91: "That (empirical) seeing, which illumines other external objects [...], has to be itself illumined by the unchanging (aparināmin) Self."

${ }^{10}$ This terminological ambiguity can also be found in Advaita where the term jñanna (cognition) is used both for consciousness and for the mental modifications (vrttis) (sometimes terminologically distinguished as sākṣijñ̄̄na or svarūpa-jñāna and vịtti-jñāna (Hiriyanna 1956, 344, Gupta 2003, 106)).

${ }^{11}$ It is in this sense, I would suggest, that the Advaitic thesis is to be interpreted that the mental acts (vrttis) that bring objects to manifestation have only a borrowed light, i.e. that ultimately it is not they that reveal the objects, the revealing factor rather being consciousness: "[A] mental mode being inert cannot by itself illuminate objects. It leads to illumination on account of its association with pure consciousness" (Gupta 2003, 108). Of course the talk of "association" is misleading here, given that vrttis have no unknown existence and that "[e]very act of cognition is an expression of pure consciousness through a mental mode" (ibid., 106). What is meant by the borrowed-light metaphor is, I think, that it is not the cognitive structures as such that explain the revealedness of objects, but these structures' being consciously present. The power of manifestation lies in consciousness as such, "the pure element of awareness in all knowing" (Hiriyanna 1956, 343).
} 
analyse how the perspectival givenness of a perceptual object involves, as the givenness of a givenness-transcendent object, the co-givenness ("appresentation") of sensuously non-given perspectives, how these co-givennesses are rooted in earlier givennesses of the same object or of objects of the same kind, etc. - but none of this is an analysis of consciousness as such. We thereby analyse how (by virtue of which kind of interplay of appearances) the givenness of a particular kind of object comes about, yet all of this plays in the medium of presence as such. Such an analysis explains how consciousness can be the consciousness of this or that kind of object, but not how it can be consciousness of the object; consciousness as such is simply presupposed. Consciousness is the taking place of presence in which all this object-appearing with all its manifold modes and structures takes place, yet in itself it has no modes or structures, and nothing to analyse. It is utter simplicity.

Husserl himself grants that if one understands "content" in the broadest possible sense, it is understood that "all differences that are predicable at all are eo ipso differences of content" (Husserl 1984, 397), yet for him this is simply trivially true and tends to conceal important differences in what "content" can phenomenologically mean. To this, I think, it has to be replied: Yes, it is a triviality, yet it is necessary to become fully aware of this triviality in order to grasp the nature of consciousness as such. Only if we conceive of contents in the broadest possible sense, encompassing anything present to us, do we get a grip on presence itself. Hence, it has to be conceded to Husserl that there are analysable richness as well as complexities in our worldexperience beyond a mere "contents are present", and that a concept of consciousness such as Natorp's is, in its radical emptiness and paucity, completely useless for the project of phenomenological investigation. Yet at the same time it is highly useful - in fact it is the decisive step - when it comes to bringing the essence of consciousness as such to light. And it is consciousness in this strict sense, in its radical emptiness and paucity, i.e. in its character as non-content, which the whole Advaitic thinking revolves around. $^{12}$

\subsection{The non-objectivity and self-luminosity of consciousness}

We never, Advaita Vedānta claims, encounter consciousness as an object (it is avișaya). It is, as it is occasionally formulated, the "not-this" (anidam) in contrast to all the "this" (idam) we experience ${ }^{13}$ : When I am asked, "Show me your consciousness", I do not know where to point: Among all the objects in the world that are there for me, my consciousness is not to be found - it is the thereness-for-me of all these objects, and this very thereness is not a part of the world that is there for me (cf. Valberg 2007, 226).

Now one could ask whether it is quite true that consciousness can never become an object of consciousness. It may be the case that it is never an object for itself, but can it not become the object of another consciousness? For example, I can remember my past consciousness and thereby make it an object of my present consciousness; and I

\footnotetext{
${ }^{12}$ As Sinha formulates: Compared to phenomenology "in Advaita, the emphasis is shifted from the question of form, pertaining to 'consciousness of', to the concrete ground of consciousness itself' (1983a, 95).

${ }^{13}$ Cf. e.g. Padmapāda 1948, 80: “[...] (ātman) which is 'consciousness entire' cannot be an object since it is of the nature of 'not this' [...]." Cf. also Śankara 1992, I.2.4: "When one has traversed the forest of 'this' [...] one arrives at one's own Ätman [...]."
} 
experience other persons (and animals) as conscious subjects, and does this not involve the givenness of their consciousness as part of the world of objects? I think the answer is no. The imagination of "other" consciousness (imagination in a broad sense, including recollection and empathy: what is called "Vergegenwärtigung", re-presentation, in contrast to "Gegenwärtigung", presentation, in Husserlian phenomenology) is fundamentally different from the imagination of anything else. When I imagine another person's consciousness I do not bring it before me as some kind of object in the world appearing to me, but put myself, by "reproducing" her consciousness, in the other's position, i.e. I imagine it as itself being world-presence. And this means that what we are actually doing when we imagine the other's consciousness is to imagine other contents of consciousness, "the world as seen from over there (from the perspective of this person)". To imagine other consciousness is always to imagine the world as given differently, never to imagine it as some item within the appearing world. In this, the givenness of the consciousness of another person is not different from the recollection of one's own past consciousness, where I imagine other contents as previously experienced. In all these imaginings, consciousness never becomes an object in the sense of one of the things that appear; rather what happens is that other contents are imagined as appearing in consciousness. ${ }^{14}$

Yet what precisely is meant by "object" when Advaita Vedānta insists that consciousness can never become an object of consciousness? Obviously it can become an object of thought (that is what is happening right now). Is the claim supposed to mean that although I can emptily (non-intuitively) intend consciousness in thinking about it, it is never intuitively given, i.e. experienced? This would go too far, since for Advaita, consciousness is something immediately given - it is just not given as an object. An object in the intended sense is, I would suggest, something I can bring "before me" (as standing opposed to me) and direct my gaze at - which involves a difference between gaze/consciousness and what is gazed at (this also includes the "immanent" experiential contents which, for Advaita, are also possible objects of consciousness). Objects of consciousness "are distinct from cognition of it [sic], they can vary in their relationship with cognition, and can be grasped by it through the standard epistemic instruments (pramānas)" (Ram-Prasad 2007, 78; cf. also Ram-Prasad 2011, 234, MacKenzie 2017, 347 f.). ${ }^{15}$ Consciousness, in contrast, is never something that stands before my gaze, but always the very gaze itself. It is only revealed in the light it itself $i s$, and is never something externally illuminated by this light, so to speak. "The sun does not need any other light for its illumination; Knowledge does not require any other knowledge than its own knowledge for its illumination" (Śankkara 1992, I.15.41; cf. ibid., I.17.40).

\footnotetext{
${ }^{14}$ Of course, the usual givenness of another person does not consist in such an explicit act of reproduction (of imaginatively putting oneself in her position); rather it consists in the givenness of an inner-worldly body being associated with the appresentative indication of the taking place of consciousness, this co-givenness only implicity functioning within the total phenomenon of "other person", and this mixed form of givenness creates the impression of the inner-worldliness of consciousness. In no way do I actually experience the other's consciousness as an empirical item within the world. When I wish to bring the appresentatively indicated consciousness to explicit givenness, I can only do this in the above-described way, by reproducing the contents of the other's consciousness, i.e. imagining the world as seen from the other's perspective. That I experience the other person as something in the world does not make her consciousness an inner-worldly object.

${ }^{15}$ Cf. also Sinha 1983b, 284: For Vedānta, consciousness "is uncognisable as an object (in the widest possible sense of objectivity, i.e., presentation in distinction from the apprehending subject)".
} 
This "it is only revealed in the light it itself is" is what the Advaitins call the selfluminosity (svaprakāśatā) of consciousness. ${ }^{16}$ By insisting that consciousness is never an object of consciousness, they by no means mean that we are not conscious of it; on the contrary, it is, in their view, the most evident of all things, the primally given: "Though it cannot be made an object of knowledge, the Self is still felt very directly. So it must be self-revealing" (Vidyāranya 1967, III.28). We are immediately aware of being conscious. As stated above: No one (not blinded by some philosophical dogma) would find the question of whether (s)he is certain that (s)he is not an unconscious automaton to not be utterly ridiculous: that my consciousness at this very moment is taking place is absolutely indubitable. ${ }^{17}$ And this indubitable evidence is not based on some inference; rather we immediately experience our own being-conscious. From what should I infer the taking place of my consciousness? It goes without saying that I do not infer from my behaviour I observe that I am obviously a conscious being (apart from the absurdity of this claim, this would hardly yield the mentioned indubitability). Perhaps one could hold that I infer from the objects of consciousness that I am conscious of them. Yet when I am, say, aware of a tree, no inferential path leads from the fact that over there stands a tree to the fact that I am conscious of it. I could only "infer" this from the fact that the tree is given to me - yet this is actually no longer an inference, since the givenness-to-me is my very consciousness of it, i.e. precisely what is supposed to be inferred. Thus, what tells me that I am conscious is not what I am conscious of, but rather nothing but my consciousness itself - consciousness involves its own revealedness. ${ }^{18}$

So my consciousness is not something I posit on the basis of some other evidence, but something I directly experience - yet not in the way I experience perceptual objects where givenness and being do not coincide and where therefore doubts about the existence of the appearing object are possible (because it is always thinkable that the appearing of the object takes place without the appearing object existing): It cannot just appear to me that I am conscious, for this very appearing would itself be consciousness. Rather, in the case of consciousness, being and givenness fall into one: presence is its own

\footnotetext{
${ }^{16}$ On the concept of svaprakāśatā cf. e.g. Indich 1980, 36-39, Ram-Prasad 2007, 75-80, Ram-Prasad 2011, $234 \mathrm{f}$.

${ }^{17}$ This is precisely the argument Śri Harșa brings forward for the self-luminosity of consciousness: It is, as Ram-Prasad paraphrases, "established by the infallibility of access to the occurrence of cognition", what includes "the absence of doubt over whether one is cognizing or not" (Ram-Prasad 2007, 75).

${ }^{18}$ That we know of our consciousness on the basis of the objects we are conscious of is indeed the claim of Dretske's "displaced perception" theory of introspection (Dretske 1995): Given the representationalist thesis that all that is given in experience are the represented objects and their properties and never experience itself, he claims that our knowledge of our own experiences is not based on an immediate awareness of them, but is rather an "indirect fact-awareness" (Dretske 1999, 113) based on the awareness of the experienced object. This is a case of what he calls "displaced perception", just as I "see" that the tank is empty by looking at the gauge on the dashboard (Dretske 1995, 41). "If you 'see' $k$ as blue and infer from this 'fact' - the 'fact' that $k$ is blue - that you are representing $k$ as blue, you cannot go wrong" (ibid., 61). Yet, it has to be countered, from this fact - the fact that $k$ is blue - it definitely does not follow that I see $k$ as blue. This can only "follow" from the fact that $k$ is given as blue (i.e. from my seeing it as blue). So my seeing $k$ as blue can only be the basis of my knowledge that I see $k$ as blue (the in itself plausible thesis that " $\mathrm{t}$ ] o know I am experiencing bluely [...] I need only the experience of blue", ibid., 63) if this seeing involves its own givenness - which is precisely what representationalism denies.
} 
presence, without any subject-object or givenness-given difference (cf. e.g. Ram-Prasad 2001, 176, Ram-Prasad 2007, 79). ${ }^{19,20}$

Hence, we do not know of our consciousness through any of the usual "means of knowledge" (pramānas) such as inference or perception. There are no special cognitive acts by which my consciousness could become known to me because its presence is the medium or base of any cognition (cf. Puligandla 2009, 43 f.). As Śankara says: "The self is not to be established by any means of right knowledge [...]. It is what employs any means of knowledge like perception, etc. in order to establish what is not already known. [...] [T] he self is the very basis of any employment of means of knowledge and is therefore established prior to them. Therefore it cannot be refuted. We can only refute what we [externally] encounter, not what is our own being, for it is the very being of him who refutes it" (1920, II.3.7, bracketed addition by Deussen; cf. Sureśvara 1959, I.89).

\section{On the relevance of the notion of prakāśa for philosophy of mind}

\subsection{Qualia and type-B materialism}

I believe Advaita's strict distinction between mental states (vrttis) and consciousness (cit) - artificial as it may seem - may be helpful in bringing an aspect of the mind into view towards which present-day philosophy of mind tends to be somewhat blind. When in the latter the talk is of consciousness, it is predominantly conceived of in terms of experiences in the sense of experiential contents, namely of "phenomenal qualities" or "qualia", i.e. qualities of certain mental states which seem to be directly accessible only to the subject that is in the respective states, and the "problem of consciousness" is understood precisely as the problem of the alleged existence of such aspects of mental states that can only be "seen" by the individual who is in these states ("mysterious,

\footnotetext{
${ }^{19}$ The picture becomes a little more complicated when one considers that vrttis too are not primarily established by pramānas (i.e. by further vrttis) but have their very being in being consciously present and thereby also leave no room, at the moment of their occurrence, for any doubt concerning their existence. The difference to the self-presence of consciousness is that, although the presence of a vrtti is not external to its being, this is in the Advaitic view (in contrast to Yogācāra's concept of svasamvedana) nonetheless not a case of self-consciousness in the strict sense, since a vrtti, being a content of consciousness (and therefore in itself not aware of anything at all), is not aware of itself (cf. Chatterjee 1982, 343) so that a difference can still be made between the vrtti and the consciousness of it.

${ }^{20}$ Perhaps one might be tempted to ask whether it is really necessary to postulate a presence of presence. What is present in consciousness is the respective phenomenal content - this being its essence qua consciousness and not consciousness itself. Is it not enough to say that what is immediately given in a way that leaves no room for any doubt of its existence are the experiential contents? Yet actually, this amounts to the same thing: To say, for example, that I am, beyond any doubt, certain of the taking-place of my present pain means that I know of its being-felt, i.e. of its experiential presence, my consciousness of it. So I am clearly aware of the taking place of consciousness. This is not a higher-order consciousness: I am not primarily aware of the phenomenal content and secondarily of my consciousness of it (no second consciousness is involved). Rather, consciousness is by virtue of its own being itself present (revealed), and it is present as presence of this or that content, and thereby, the content too is ipso facto present ("What is put in - superimposed on - the transparency of consciousness [scil. the respective mental state] is also transparent to consciousness", RamPrasad 2007, 82.) The "shining" of consciousness is the medium in which any object-disclosure happens, the mode of being of manifestation of anything. "What is not self-luminous is not illuminating" (Saksena 1971, 71).
} 
nonpublic objects", Metzinger 2003, 591). Antimaterialists argue that no matter how completely a brain and its states, the latter's functional roles and so on are described, something has been left out, "you won't have told me about the hurtfulness of pains, the itchiness of itches, pangs of jealousy, or about the characteristic experience of tasting a lemon", as Jackson formulates $(1982,127)$. So there seem to be aspects of our conscious mind that are irreducible to what is externally observable about us, and this poses a problem for physicalism, given that the physical is the objectively accessible par excellence (cf. e.g. Dretske 1995, 65).

This reasoning is, I think, perfectly sound, but at the same time it tends to obscure the basic problem. Today there is a strong tendency to simply equate consciousness with the qualia. ${ }^{21}$ Yet there is clearly something not quite right about this. The "itchiness of itches" and the "hurtfulness of pain" are qualities we are conscious of. So philosophy of mind tends to treat consciousness as if it consisted simply of the contents of consciousness (the phenomenal qualities), while it really is precisely consciousness of contents, the very givenness of whatever is subjectively given. And therefore the problem of consciousness does not pertain so much to some alleged "mysterious, nonpublic objects", i.e. objects that seem to be only "visible" to the respective subject, but rather to the nature of "seeing" itself (and in today's philosophy of mind astonishingly little is said about the latter). ${ }^{22}$

This, I think, is the lesson of the Advaitic understanding of consciousness as prakāśa: For Advaita Vedānta, the distinction between external, publicly accessible objects and subjective ones (experiences) is not the relevant distinction when it comes to consciousness. The Advaitins indeed hold that experiences (vrttis) qua inner-mental goings-on are only privately given in contrast to the external objects. Yet both are seen as objects of consciousness; the relevant distinction with regard to consciousness is that between any objects of consciousness and consciousness itself - the presence of

\footnotetext{
${ }^{21}$ To cite just a few random examples: Goff has recently spoken of "redness" - i.e. the experiential red-quale as "a form of conscious experience" $(2017,14)$; Metzinger writes: "In the philosophy of mind this pure experience is termed the phenomenal content of our mental states" (1995, 8); Tye formulates: "[A] mental state is phenomenally conscious just in case there is some immediate 'feel' to the state, some distinctive experiential quality" (Tye 1995, 3); and for Frankish to be "phenomenally conscious" means to have experiences with certain "introspectable qualitative properties" $(2016,13)$.

22 The concentration of the consciousness-debate on the qualia might create the impression that one could solve the problem of consciousness by getting rid of these infamous nonpublic objects. For example reductive representationalists hold, based on the transparency observation about consciousness, that conscious states are states by which we are conscious of something and not states we are conscious of (Dretske 1995, $100 \mathrm{f}$.). In their interpretation, this means that there simply is no such thing as qualia in the sense of intrinsic and essentially private qualities of experience, all we are ever aware of in experience are actually objective properties external objects are represented as having. So consciousness exhausts its being in its representational function, and presupposing that representation is a feature of the mind that can in principle be quite easily accounted for physicalistically (in terms of causal covariation, indicator functions and the like), representationalism argues that the problem of consciousness is therefore dissolved (cf. e.g. Dretske 1995, Tye 1995, Harman 1990). - The problem with this kind of account is that what is described as representation in naturalistic terms in no way amounts to the same thing as conscious presence: Any state that, according to naturalistic criteria, "represents" something is compatible with no conscious presence-of-something taking place at all (cf. McGinn 1997, Warfield 1999, Chalmers 2010, 349-353). The purported fact that what is present in experience are only objective qualities not at all implies that this very presence itself has been reduced to the objective, and the problem of consciousness remains as hard as ever - simply because presence, the for-ness of something for an experiencing subject, has not been accounted for. The problem of consciousness does not primarily consist in the experiential presence of only subjectively accessible qualities, but in the presence of any contents at all - i.e. it is precisely the problem of consciousness.
} 
whatever contents: prakāśa. And it is this presence as such that the problem of consciousness is really about.

To be fair, the central (Nagelian) phrase used today to characterize conscious experience, namely that there is "something it is like" to undergo it, very well seems to imply the presence-aspect. It is like something to undergo an experience for the respective experiencer, and what else could this mean but that this experience is there for the latter, with this for-ness referring precisely to the experiential presence of a respective experiential content. ${ }^{23}$ Yet, again, present-day philosophy of mind has very little to say about this presence-aspect, and this phrase is notoriously misunderstood by simply identifying the what-it-is-like-ness of experience with certain, only privately accessible, experiential qualities. Quite typical in this respect is, e.g., what Tye has to say about what-it-is-like-ness in his "Qualia" entry in the Stanford Encyclopedia of Philosophy:

"What it is like to undergo the experience [of staring at a bright turquoise color patch] is very different from what it is like for you to experience a dull brown color patch. This difference is a difference in what is often called 'phenomenal character'. The phenomenal character of an experience is what it is like subjectively to undergo the experience. If you are told to focus your attention upon the phenomenal character of your experience, you will find that in doing so you are aware of certain qualities. These qualities - ones that are accessible to you when you introspect and that together make up the phenomenal character of your experience [-] are sometimes called 'qualia"” (Tye 2018, my emphasis).

Here what it is like to undergo an experience is expressly equated with the "phenomenal character", which is nothing other than the experiential qualities ("qualia") one finds when reflecting on one's experience, and it is these qualia which are, as he writes further, "at the heart of the mind-body problem". Quite similarly, to quote one last example, Chalmers writes with reference to Dennett's "Quining Qualia" paper that " $[\mathrm{t}]$ he term 'qualia' [...] refers to the properties of mental states that characterize what it is like to have them" (Chalmers 2002b, 198), and these qualia are for Dennett "immediate phenomenological qualities", which are "essentially private" (the existence of which Dennett of course denies) (Dennett 2002, 229). So while the phrase "what it is like" really refers to the phenomenon of presence-of-content as a whole, the debate usually swiftly shifts to the content aspect alone.

Now when consciousness is conceived in terms of only "introspectively" accessible, "nonpublic" objects, there is a danger of missing the central point about the problem of consciousness: then the - presently quite popular - materialist reply suggests itself that

\footnotetext{
${ }^{23}$ As Timothy Sprigge - who, as Nagel acknowledges, originally coined the phrase - formulates: "There are two sorts of truth one may know about a human being. One may know what he is like, or one may know what it is like being him" (Sprigge 1983, 1). "To know what it is like to be another person at a certain moment [...] is to imagine more or less fully something of how that person feels to himself, and how his environing world appears to him", i.e. "to have a sense of how he and the world are presented to himself' (ibid., 2). The point is that the second question is one that only makes sense with regard to conscious beings: As regards merely objectively existing entities, it is impossible to imagine how this entity itself and the world are presented to it, simply because no presenting, no appearing, happens in the first place. Therefore this presence is what is really at issue when we consider the phenomenon that there is "something it is like" to be an experiencing creature (and Sprigge is quite explicit that this is not only a matter of the experiences being present to the subject, but also the world; cf. also ibid., 3, and Sprigge 2011, 43).
} 
there is actually no reason to suppose that conscious states are only privately accessible; if they are identical to physical states they are publicly accessible, it is only that they are accessible to the one who is in the respective states in a different way than to an external observer. It is illegitimate to infer an ontological difference with regard to what is given from an epistemological difference of modes of givenness. As Churchland says: "[T]he difference between a person who knows all about the visual cortex but has never enjoyed a sensation of red, and a person who knows no neuroscience but knows well the sensation of red, may reside not in what is respectively known by each (a brain state by the former, qualia by the latter), but rather in the different type of knowledge each has of exactly the same thing" $(1985,24)$. "After all, we know that the two epistemic modalities of vision and touch, for example, are not mutually exclusive in the phenomena they access [...]. Why should it be impossible a priori that the epistemic modality we call 'introspection' have some similar overlap with one or more of our other epistemic modalities" (1996, 227; cf. Hill 2002, 337)?

This kind of reasoning is the basis of what Chalmers calls type-B materialism. While type-A materialism denies any epistemic gap between physical truths and truths about consciousness (so that if everything that can be said about a person in physical terms is said, no aspect remains unaccounted for), type-B materialism concedes this gap but declares it to be merely an epistemic matter without any necessary ontological consequences (Chalmers 2002a). That it is conceivable that a certain neural event takes place without the corresponding conscious experience existing in no way implies that they are not in fact identical. After all, identities of entities referred to in different ways are often an a posteriori matter: Just as the identity of light and electromagnetic waves of certain wavelengths is an empirical discovery and not an analytical truth, what we refer to as an experience might as well be some brain state, although we cannot know this a priori - it is "a difference at the level of sense, not reference" (Papineau 2002, 49).

Hill, for example, argues - following a footnote in Nagel's "Bat" paper - that the possibility of imagining conscious states without the corresponding brain states and vice versa does not have to mean that what is imagined is different, but might very well be due to the fact that we are dealing here with two different modes of imagination that can be performed independently (Hill 2002): To imagine a brain state means to execute a "perceptual imagination", i.e. to put oneself in a state that resembles a perception of a brain state (or rather of a brain scan), while to imagine an experience means to imagine the state "sympathetically", i.e. to put oneself in a state that resembles the imagined state itself. Therefore it is no surprise that one can perform the one kind of imagination without the other. What is distinct are not the brain state and the conscious state, but the imaginative reproduction of a brain state and the imaginative reproduction of the perception of a brain state. Quite similarly, Papineau argues that the "'third-person' way" of thinking of brain states does not involve - as does the " "first-person' way" - a "re-creation" of the states themselves and therefore does not "feel" like them (1995, 260-262), and this creates the impression (the "intuition of distinctness", 2002, 2 et pass.) that something is left out (namely the very "feel" itself). Yet this is a fallacy: Not to use a state in referring to it does not imply that one is not referring to it $(1995,263)$.

In light of the above considerations about the nature of consciousness qua presence or manifestation, there is clearly something amiss in this kind of argumentation. The basic question is why the "re-creation" of a brain state should be a way of imagining it 
at all. This presupposes - and therefore does not explain - that to be in this state involves the givenness of this state in the first place (after all, the re-creation of a nonconscious physical state - and be it a brain state - in no way means imagining this state, i.e. bringing it to conscious givenness); and the fundamental question when it comes to the nature of consciousness is precisely what this very givenness itself is and whether it can be accounted for in physical terms. It is no problem to understand that a brain state is experienced differently by the one who is in this state than by someone who externally observes it. Yet the problem of consciousness is not about what might be given in consciousness (what is experienced) - this might very well be identical with what can also be given differently - but precisely about consciousness (experiencing) itself, which in this kind of account is simply taken for granted.

In one passage, Papineau writes that he does not deny "that it's like something to be in those physical states [...]. Of course it is like something to smell thyme or feel depressed. All I say is that this isn't anything different from being in the relevant physical states. The phrase 'what it's like' doesn't refer to anything non-physical, but just to the presence of the physical state for the individual that has it" $(1995,265)$. I think this formulation of his is quite remarkable: Only a few lines after denying that there is something like an "inner light" of consciousness that would have to be explained in addition to the physical goings-on (ibid.) he suddenly speaks of presence-of-for - and it remains quite unclear why the mere existence of a physical state should amount to the presence of this state for an experiencing subject. This is hardly implied by any physical account of what goes on in an organism. And it is precisely this presence that Papineau simply presupposes the "problem of consciousness" is all about, and not what might be present in this presence (even if this should be a brain state).

In his other writings, Papineau seems to shun the formulation of presence-of-for, but it is hard to see how he can do without this presence. His whole account assumes that the problem of consciousness is about the contents of consciousness, and the physicalist identity claim concerns what we are conscious of in first-personal givenness and in third-personal modes of reference. This is quite obvious when he writes, for example: "There is no doubt that we are all subject to a strong 'intuition of distinctness'. How can the feelings - the colours, the smells, the excitement - possibly be the same as grey mushy brain states" $(2006,103)$ ? "Colours", "smells", and so on are clearly phenomenal contents of consciousness, and their seeming difference to brain states rests, in Papineau's view, in the special way we refer to what is really a brain state, namely "in terms of what it is like" $(2002,149)$. And what should this "what it is like" be other than the way the state in question is given in experience, i.e. its presence-for-me (and what else should this presence be than the repudiated "inner light" of consciousness - again: prakāśa, which literally means "light")?

\subsection{Presence and materialism}

The problem of consciousness is precisely the problem of consciousness, and it is the nature of consciousness qua presence that, I contend, is actually at the heart of the usual antimaterialist argumentation, though this tends to be obscured by the concentration on the qualia and their purported peculiarities. The qualia-based antimaterialist argumentation is often understood as if it were saying that experiences have, as introspection tells us, certain qualitative properties that seem to be distinct from physical properties 
(cf. e.g. Frankish 2016, 13, Goff 2017, 106, Papineau 2006, 103). To this, as we have seen, the physicalist could reply that it might be the case that introspection presents experiences in that way, but that this may not reveal their true, physical nature. The antimaterialist might counter that this is not plausible: When I introspectively attend to my pain, I certainly have a clear grasp of what it means to be in pain. "[W]e are", Goff writes, "in a unique epistemic situation with respect to our conscious states" so that their nature and existence is knowable with certainty by the respective subject (what Goff calls "Revelation") (2017, 107), and this is simply because they are "directly presented" (ibid.) to the subject, i.e. "the feeling is 'right there' for you" (ibid., 108). ${ }^{24} \mathrm{I}$ think this is completely correct - yet if one starts with the allegedly non-physical nature of the properties of qualia and then, additionally, maintains that these properties are directly and error-immunely presented, one could ask why one should assume the latter: If experiences really are physical events, such immediate revealedness is precisely what seems to be impossible in the first place, since any representation of physical states by a physical system requires some mediating representational mechanism.

As quoted above, for Goff, "redness" is an example of a state of consciousness $(2017,14)$, and with regard to such a quality, its revealedness seems to be an additional claim. Yet as I have argued above, consciousness really is nothing other than the "right-there-ness" or presentedness itself, and I think it is at this presence where the antimaterialist argumentation has to start. What cannot be explained away by the different-modes-of-givenness strategy is givenness itself, and this naturally involves the respective phenomenal content as phenomenal (i.e. experienced) content (for presence consists in the thereness-for-me of what it is presence of - this was the lesson of transparency). In the case of experiences (phenomenal contents), being and appearing fall into one (so that the claim that they might appear differently than they really are makes no sense) for the simple reason that by experiences we mean nothing other than the experienced precisely as it is experienced. One is free to define "pain" as something that comes to givenness in pain-experience and which might be something that possesses givenness-transcendent existence and be of a (physical) nature not revealed in experience - yet what is actually meant when the talk is of pain and its immediate presentedness is really nothing other than the pain-experience itself, i.e. our experiencing (feeling) pain (the experiential presence of pain), which necessarily involves the pain-asexperienced (the phenomenal content as phenomenal content). So the crucial point is not the peculiarities of the contents that are presented to us in experiencing, but their very presentedness (the experiencing) itself. What the antimaterialist is actually saying is that the fact that qualia (or whatever) are experienced is not implied by the physical facts, hence it is really this experiencing that is at the heart of this kind of reasoning.

Hence, what I wish to say is not that there is anything basically wrong with the usual whatit-is-like-based antimaterialist argumentation but only that it is important to be clear about what the crucial point is in order to block inadequate materialist responses from the start. The what-it-is-like-ness or "phenomenal character" of experiential states means, in my view, nothing other than that these states are, in being experienced, experientially present (e.g., that there is something it is like for the subject to be in pain means that the pain is experientially

\footnotetext{
${ }^{24}$ Cf. also Chalmers' claim that we are "directly acquainted" with phenomenal properties, acquaintance being "a basic sort of epistemic relation between a subject and a property" $(2010,287)$ that makes a "lucid understanding of phenomenal properties" possible (ibid., 285).
} 
present to her). Yet the "what it is like" phrase refers in an undifferentiated way to the phenomenon of presence-of-experiential-content as a whole, and this invites us to focus on the nature of the experiential contents and their alleged peculiar nature (their privacy, their qualitative and therefore functionally irreducible character, etc.) instead of presence itself. This is where, to my mind, the strict Advaitic distinction between any content of consciousness and consciousness itself helps us to clarify the matters at hand.

Now, could the physicalist not just say the same thing she does about the contents of consciousness in regard to consciousness itself: that it is in fact identical to some physical feature? Yet what is this supposed to mean? The type-B materialist strategy cannot be applied here: One cannot explain the seeming difference between the physical and consciousness through a special way we refer to a physical state, namely in terms of how it is first-personally given, since this would presuppose consciousness (givenness) as what it is (and not as something that is perhaps given first-personally as conscious presence, but might be in its true nature something quite different). That is, it makes no sense to say that maybe consciousness is really something physical that only appears as consciousness, ${ }^{25}$ because consciousness is this very appearing; and to say that appearing only appears as appearing obviously leads into an infinite regress.

So the type-B strategy - relying as it does on different modes of givenness - makes no sense when it comes to consciousness (givenness itself). Instead of saying that consciousness is really something physical that only appears as conscious presence, the physicalist would have to demonstrate how the physical could be conscious presence. But does this make sense? Of course this depends on what one understands by the physical, yet I suppose it is fair to take as a minimal definition that the physical is what physics informs us about and that, furthermore - regardless of the change in what kinds of entities physics accepts as existing throughout its history - specifically mental concepts are not part of the basic vocabulary of physics and that therefore mental properties do not belong to the fundamental features of reality as postulated by physics. At least this understanding of the physical (as "mere insentient matter", so to speak) corresponds to the basic intention of materialism in the usual sense: the claim that the mental is not an irreducible feature of reality, but is somehow identical or reducible to merely physical, i.e. non-mental entities, processes or properties (and vice versa, this is precisely what antimaterialism argues against). ${ }^{26}$

\footnotetext{
${ }^{25}$ Unless one understands "to appear" in a purely third-personally conceived way (cf. Frankish 2016, 14, Chalmers 2018, 52), e.g. as the disposition to utter sentences concerning one's consciousness. Yet it is hardly plausible that, for example, a computer that is programmed in such a way that it is disposed to formulate sentences like "I am conscious" or "I am in pain" is ipso facto experiencing its being conscious or feeling pain in the same sense as we do (and the same holds for any non-consciousness-involving construal of what "to appear" might amount to).

${ }^{26}$ Of course one is free to define the physical differently. Yet if one leaves out in one's definition the nonmental character of the fundamental physical features, physicalism threatens to become a quite empty thesis. Galen Strawson, for example, argues that "the physical" is a natural-kind term that does not a priori determine the nature of what it refers to, which might as well be experiential (Strawson 2006b). I think this kind of understanding of the physical makes perfect sense (and I have a good deal of sympathy for the panpsychist consequences Strawson draws). But it is not very useful when it comes to a definition of physicalism in contrast to competing views, for if even "pure panpsychism" - the view that all being is intrinsically of a purely experiential nature (Strawson 2006a, 227) (and therefore a kind of "psychicalism" as the very opposite of physicalism in the usual sense) - has to count as physicalism, the latter is no longer a metaphysically overly substantial thesis. At any rate, this is not the way physicalism is normally understood and not at all what antiphysicalism (as the thesis that there are mental features that are not reducible to anything else, i.e. to something non-mental) argues against.
} 
In light of this understanding of the physical, the identification of consciousness with some basic physical feature clearly makes no sense at all. Rather, physicalism must claim that consciousness is ontologically reducible to physical features, ${ }^{27}$ i.e. that it is constituted by a certain configuration of in themselves non-mental items (e.g. configurations that constitute certain forms of "representational" states, as representationalism holds). Yet the problem is that consciousness does not at all appear to be constituted by non-conscious elements. Conscious presence is not something objectively given, and it is hard to understand how an agglomeration of objects should ever ipso facto amount to what is essentially never an object. So if no configuration of nonconsciousness-involving elements logically implies that conscious presence takes place, we are led back to the type-B figure of thought that the way conscious presence appears to us does not reveal its true, physical nature - and then we are again confronted with the problem that we have to presuppose as unreduced that whose ontological reducibility we intended to demonstrate.

\subsection{Presence and the world of objects}

From an Advaitic perspective, the fundamental point against materialism is not that within the world we encounter certain objects which have characteristics that are in some sense "non-material", but rather the radical difference between whatever we can encounter as an object on the one hand and what is never an object of consciousness but always only consciousness of objects on the other (cf. Ram-Prasad 2007, 98 f.). ${ }^{28}$ Consciousness is not something within the objective world, but rather the mere "witness" (sākșin) - the happening of manifestation - of the world. For Advaita, it makes no sense to view what is never given to us as an object as a part of the world of objects, and a fortiori it is nothing physical: Physics deals with the externally observable (i.e. what is given to us as givenness-transcendent objects) and what can be posited by explanatory inference on the basis of the externally observed; and consciousness the appearing itself - is neither one of the objects encountered within the appearing world, nor does any inferential path lead from the objectively observable facts to the existence of consciousness. Consciousness is the place wherein the presence of the object-world unfolds, yet it is not itself part of this world.

Now the question could arise as to whether this really marks such a decisive ontological divide, i.e. whether the fact that we never encounter our consciousness as an object in the world we are conscious of is not perhaps merely an epistemological matter that should not be over-interpreted in an ontological way, namely in the sense of its radical non-worldliness: that for our consciousness of objects, this consciousness does not appear as one of the objects does

\footnotetext{
${ }^{27}$ By ontological reducibility I mean that the holding of some fact consists in nothing over and above the holding of some other facts (to which it is therefore reducible), in contrast e.g. to the reducibility of statements of one sort to statements of some other sort (i.e. the former's translatability).

${ }^{28}$ Cf. e.g. Śankara's commentary on the Kața Upanișad, III.1.3: "Since the aggregate of body etc., is substantially indistinguishable from (knowable objects like) sound, etc., and hence it, too, is equally a knowable, it cannot reasonably be the knower. If the aggregate of body etc., though constituted by colour etc., can perceive colour etc., then the external colour etc., may as well know each other as also their own individual feature. But this does not tally with facts. Therefore [...] people perceive colour and other attributes, in the form of the body etc., etena eva, through this only - through the Self which is consciousness by nature and which is distinct from the body etc." $(1977,174)$.
} 
not exclude, one could suggest, the possibility that it de facto is part of the object-world - just as a picture does not itself feature as one of the objects pictured, which does not at all imply that it is not a totally normal object just like any of the things it represents. Yet this analogy does not work: A picture is something seen that additionally functions as representation-of, and therefore, even if it is not part of what it pictures, it can be pictured, i.e. it can feature as part of the subject of another picture. Consciousness, in contrast, is never something seen but always only the seeing itself. That is to say, consciousness is not some object that additionally functions as representation-of (this might be thinkable of the "presenting data" - the "mental paint" (Harman 1990, 667), if such a thing exists - yet they are themselves something we are conscious of and not consciousness itself, the mere presence of whatever we are conscious of). Consciousness is never an object of consciousness, including any other consciousness: As discussed above, to imagine "another" consciousness never means anything other than imagining other contents being present to consciousness - the "inwardness" of consciousness is never left in this way; it is never encountered "from the outside".

Still, one could ask whether consciousness, even if it does not appear as consciousness within the objective world, could nonetheless be identical with something differently given, something we encounter "from the outside" as something objective - now in a non-physicalistic sense, i.e. without saying that what subjectively appears as consciousness really is something in itself purely objective, but instead saying, vice versa, that what is in itself consciousness might externally appear as this or that objective feature. (I am thinking here of dual-aspect views just like, e.g., what is nowadays sometimes called "Russellian monism" (cf. e.g. Goff 2017).) Yet it is doubtful that this makes much sense. The objective is what appears to consciousness as distinguished from it (i.e. from its being-there-for-me), and therefore it can be there for me in different ways without itself being different for that reason. It makes perfect sense to say that this chair which is now given in this way could, as one and the same chair, also be given in some other way, and it can not only be given as a chair in different ways but also as something else, e.g. for a physicist as an agglomeration of molecules. Yet this is only possible because its givenness is external to its being: The chair can be given even if it is not given as a chair because its givenness-as-achair is distinguished from its being so that what can be considered in one respect as an agglomeration of molecules can also be considered with regard to its function as a chair. Presence, in contrast, is not given in an appearance that can be distinguished from its being. And this means that by presence we do not mean something that, among others, possesses the aspect of being presence, but rather nothing but the presence-"aspect" itself. So it might make sense to say that a particular mental event can be taken in a different respect than with regard to its first-personal presence, that it has an "exterior side" that locates it in some way within the objective world. Yet consciousness is nothing but this presence itself, and whatever I can observe about a 
mental event "from the outside", independently from the aspect of its beingsubjectively-given, is ipso facto not the aspect of conscious presence. ${ }^{29}$ Consciousness is only there for us in the light it itself is; from "outside itself", presence is not given differently, but simply not at all. It is the absolutely non-distanceable, it has no "exterior side" one could encounter from the outside, as any object whatsoever.

\section{Summary}

Advaita Vedānta insists on the ontological uniqueness of consciousness: It is fundamentally different from anything we ever encounter as an object of consciousness, as different as "light" is from "darkness", as Śankara says in the initial statement of his Brahmasutrabhasya (1920, Intr.). Consciousness is the taking place of presence (prakāśa) of objects, and whatever we encounter as a content of consciousness is precisely another content of consciousness and not the consciousness of the contents: "Sound and the other [external objects of knowledge] are not perceived by themselves, nor are they perceived by each other" (1992, I.14.41, bracketed addition by Mayeda; cf. also 1920, III.3.54). So Advaita, in its insistence on the specialness of consciousness, is not simply saying that it is an object of a very special kind (a "mental" object with seemingly nonphysical properties) but that it is not an object at all: it is the non-objective kat' exochen, pure subjectivity.

As I have argued, today's philosophy of mind tends to miss the basic point about the problem of consciousness by not having a clear grasp of this nature of consciousness qua presence. It conceives of it mostly in terms of "phenomenal qualities", "feels" and the like, thereby taking it as a special kind of (introspectively accessible) object. This renders the antimaterialist claim of the distinctness of consciousness from physical (publicly accessible) features vulnerable to the reply that the difference in question might be a merely epistemological matter, i.e. one of different modes of givenness (introspective and third-personal, respectively) without a difference of what is thus given. This move, however, is not possible without circularity or infinite regress with regard to givenness itself, i.e. consciousness in the strict sense. ${ }^{30}$

Funding Information Open access funding provided by University of Vienna.

Open Access This article is licensed under a Creative Commons Attribution 4.0 International License, which permits use, sharing, adaptation, distribution and reproduction in any medium or format, as long as you give appropriate credit to the original author(s) and the source, provide a link to the Creative Commons licence, and indicate if changes were made. The images or other third party material in this article are included in the article's Creative Commons licence, unless indicated otherwise in a credit line to the material. If material is not

\footnotetext{
${ }^{29}$ To be more precise: The "Russellian monist" view holds that physics "captures only the relational, dispositional, extrinsic or structural properties of matter" (Goff 2017, 17), not its intrinsic nature - the point being, however, that presence as such has simply no structural etc. features, all structures exclusively pertaining to the contents of consciousness.

${ }^{30}$ I would like to thank two anonymous reviewers of an earlier version of this paper for their helpful comments.
} 
included in the article's Creative Commons licence and your intended use is not permitted by statutory regulation or exceeds the permitted use, you will need to obtain permission directly from the copyright holder. To view a copy of this licence, visit http://creativecommons.org/licenses/by/4.0/.

\section{References}

Balslev, A. N. (2013). Aham: I. The enigma of I-consciousness. New Delhi: Oxford University Press.

Chalmers, D. J. (2002a). Consciousness and its place in nature. In D. J. Chalmers (Ed.), Philosophy of mind. Classical and contemporary readings (pp. 247-272). New York/Oxford: Oxford University Press.

Chalmers, D. J. (Ed.) (2002b). Philosophy of mind. Classical and contemporary readings. New York/Oxford: Oxford University Press.

Chalmers, D. J. (2010). The character of consciousness. Oxford/New York.

Chalmers, D. J. (2018). The meta-problem of consciousness. Journal of Consciousness Studies, 25(9-10), 661.

Chatterjee, A. K., \& Dravid, R. R. (1979). The concept of sākși in Advaita Vedānta. Varanasi: Banaras Hindu University Press.

Chatterjee, T. (1982). The concept of sākșin. Journal of Indian Philosophy, 10, 339-356.

Churchland, P. M. (1985). Reduction, qualia, and the direct introspection of brain states. Journal of Philosophy, 82, 8-28.

Churchland, P. M. (1996). The rediscovery of light. Journal of Philosophy, 93(5), 211-228.

Dennett, D. C. (2002). Quining qualia. In D. J. Chalmers (Ed.), Philosophy of mind. Classical and contemporary readings (pp. 226-246). New York/Oxford: Oxford University Press.

Dretske, F. (1995). Naturalizing the mind. Cambridge: MIT Press.

Dretske, F. (1999). The mind's awareness of itself. Philosophical Studies, 95, 103-124.

Fasching, W. (2012). On the Advaitic identification of self and consciousness. In I. Kuznetsova, J. Garneri, C. Ram-Prasad (Eds.), Hindu und Buddhist ideas in dialogue. Self and no-self (pp. 165-180). Farnham: Ashgate.

Frankish, K. (2016). Illusionism as a theory of consciousness. Journal of Consciousness Studies, 11-12, 1139.

Goff, P. (2017). Consciousness and fundamental reality. New York: Oxford University Press.

Gupta, B. (1998). The disinterested witness. A fragment of Advaita Vedānta phenomenology. Evanston: Northwestern University Press.

Gupta, B. (2003). Cit. Consciousness. New Delhi: Oxford University Press.

Harman, G. (1990). The intrinsic quality of experience. Philosophical Perspectives, 4, 31-52.

Hill, C. (2002). Imaginability, conceivability, possibility, and the mind-body problem. In D. J. Chalmers (Ed.), Philosophy of mind. Classical and contemporary readings (pp. 334-341). New York/Oxford: Oxford University Press.

Hiriyanna, M. (1956). Outlines of Indian philosophy. London: George Allen \& Unwin.

Husserl, E. (1984). Logische Untersuchungen. Zweiter Band, erster Teil: Untersuchungen zur Phänomenologie und Theorie der Erkenntnis. Ed. by Ursula Panzer. The Hague: Nijhoff (Husserliana $\mathrm{XIX} / 1$ ).

Indich, W. M. (1980). Consciousness in Advaita Vedānta. Delhi: Motilal Banarsidass.

Jackson, F. (1982). Epiphenomenal qualia. The Philosophical Quarterly, 32, 127-136.

MacKenzie, M. (2012). Luminosity, subjectivity, and temporality. An examination of Buddhist and Advaita views of consciousness. In I. Kuznetsova, J. Ganeri, \& C. Ram-Prasad (Eds.), Hindu and Buddhist ideas in dialogue. Self and no-self (pp. 181-198). Farnham: Ashgate.

MacKenzie, M. (2017). Luminous mind. Self-luminosity versus other-luminosity in Indian philosophy of mind. In J. Tuske (Ed.), The Bloomsbury research handbook to Indian epistemology and metaphysics (pp. 335-353). Bloomsbury Academic.

McGinn, C. (1997). Missing the mind. Consciousness in the swamps. Noûs, 31, 528-537.

Metzinger, T. (1995). The problem of consciousness. In T. Metzinger (Ed.), Conscious experience (pp. 3-37). Schöningh: Paderborn.

Metzinger, T. (2003). Being no one. The self-model theory of subjectivity. Cambridge: MIT Press.

Mohanty, J. N. (1993). Consciousness in Vedānta. In Essays on Indian philosophy (pp. 56-67). Oxford/New York: Oxford University Press.

Natorp, P. (1888). Einleitung in die Psychologie nach kritischer Methode. Freiburg: Mohr. 
Padmapāda (1948). The Pañcapādikā of Padmapāda. Transl. by D. Venkataramiah. Baroda: Oriental Institute. Papineau, D. (1995). The antipathetic fallacy and the boundaries of consciousness. In T. Metzinger (Ed.), Conscious experience (pp. 259-270). Schöningh: Paderborn.

Papineau, D. (2002). Thinking about consciousness. Oxford: Oxford University Press.

Papineau, D. (2006). Comments on Galen Strawson. In A. Freeman (Ed.), Consciousness and its place in nature. Does physicalism entail panpsychism? (pp. 100-109). Exeter/Charlottesville: Imprint Academic.

Puligandla, R. (2009). That thou art. The wisdom of the Upaniṣads. New Delhi: D. K. Printworld.

Ram-Prasad, C. (2001). Knowledge and liberation in classical Indian thought. Basingstoke: Palgrave.

Ram-Prasad, C. (2002). Advaita epistemology and metaphysics. London: Routledge Curzon.

Ram-Prasad, C. (2007). Indian philosophy and the consequences of knowledge. Themes in ethics, metaphysics and soteriology. Aldershot: Ashgate.

Ram-Prasad, C. (2011). Situating the elusive self of Advaita Vedānta. In M. Siderits, E. Thompson, \& D. Zahavi (Eds.), Self, no self? Perspectives from analytical, phenomenological, and Indian traditions (pp. 217-238). Oxford: Oxford University Press.

Saksena S. K. (1971). Nature of consciousness in Hindu philosophy. Delhi: Motilal Banarsidass.

Śankara (1920). Die Sûtra's des Vedânta oder die Çârîraka-Mîmânisâ des Bâdarâyana nebst dem vollständigen Commentare des Çañkara. Transl. by P. Deussen. Leipzig: Brockhaus.

Śankara (1977). Eight Upaniṣads. Volume One. With the Commentary of Śankarācārya. Transl. by Swami Gambhirananda. Calcutta: Advaita Ashrama.

Śankara (1992). A thousand teachings. The Upadeśasāhasrī of Śañkara. Transl. by Sengaku Mayeda. Albany: State University of New York Press.

Sinha, D. (1983a). Metaphysic of experience in Advaita Vedānta. A phenomenological approach. Delhi: Motilal Banarsidass.

Sinha, D. (1983b). The phenomenological perspective and the Indian philosophical tradition. Indian Philosophical Quarterly, 10(3), 277-293.

Sprigge, T. L. S. (1983). The vindication of absolute idealism. Edinburgh: Edinburgh University Press.

Sprigge, T. L. S. (2011). The importance of subjectivity. Selected essays in metaphysics and ethics. Ed. by L. B. McHenry. Oxford: Clarendon Press.

Strawson, G. (2006a). Panpsychism? Reply to commentators with a celebration of Descartes. In A. Freeman (Ed.), Consciousness and its place in nature. Does physicalism entail panpsychism? (pp. 184-280). Exeter/Charottesville: Imprint Academic.

Strawson, G. (2006b). Realistic monism. Why physicalism entails panpsychism. In A. Freeman (Ed.), Consciousness and its place in nature. Does physicalism entail panpsychism? (pp. 3-31). Exeter/ Charottesville: Imprint Academic.

Sureśvara (1959). The realization of the absolute. The "Naișkarmya siddhi” of Sri Sureśvara. Transl. by A. J. Alston. London: Shanti Sadan.

Tye, M. (1995). Ten problems of consciousness. A representational theory of the phenomenal mind. Cambridge: MIT Press.

Tye, M. (2018). Qualia. In E. N. Zalta (Ed.), The Stanford encyclopedia of philosophy. Summer 2018 edition. https://plato.stanford.edu/archives/sum2018/entries/qualia/. Accessed 29 March 2020.

Valberg, J. J. (2007). Dream, death, and the self. Princeton: Princeton University Press.

Vidyāranya (1967). Pañcadaśí. Transl. and comm. by Swāmi Swāhānanda. Mylapore: Sri Ramakrishna Math.

Warfield, T. A. (1999). Against representational theories of consciousness. Journal of Consciousness Studies, 6(1), 66-69.

Zahavi, D. (2005). Subjectivity and selfhood. Investigating the first-person perspective. Cambridge: MIT Press.

Publisher's note Springer Nature remains neutral with regard to jurisdictional claims in published maps and institutional affiliations. 